\title{
Tolerance of Glyphosate-Resistant Maize to Glyphosate Plus MCPA Amine Is Influenced by Dose and Timing
}

\author{
Nader Soltani, ${ }^{1}$ Kris McNaughton, ${ }^{1}$ Chris L. Gillard, ${ }^{1}$ \\ Robert E. Nurse, ${ }^{2}$ and Peter H. Sikkema ${ }^{1}$ \\ ${ }^{1}$ University of Guelph Ridgetown Campus, Ridgetown, ON, Canada NOP 2CO \\ ${ }^{2}$ Agriculture and Agri-Food Canada, 2585 Country Road 20, Harrow, ON, Canada NOR 1G0 \\ Correspondence should be addressed to Nader Soltani; soltanin@uoguelph.ca
}

Received 25 May 2015; Accepted 5 July 2015

Academic Editor: Kassim Al-Khatib

Copyright (C) 2015 Nader Soltani et al. This is an open access article distributed under the Creative Commons Attribution License, which permits unrestricted use, distribution, and reproduction in any medium, provided the original work is properly cited.

\begin{abstract}
There is little information on tolerance of glyphosate-resistant maize to glyphosate plus MCPA amine as influenced by dose and timing under Ontario environmental conditions. A total of seven field trials were conducted at various locations in Ontario, Canada, in 2011-2013 to evaluate tolerance of field maize to tank mixes of glyphosate ( $900 \mathrm{~g}$ a.e./ha) plus MCPA amine $(79,158,315,630,1260$, 2520 , or $5040 \mathrm{~g}$ a.e./ha) at either the 4 - or 8-leaf stage. The predicted dose of MCPA amine that caused 5, 10, and 20\% injury was 339 , 751, and $1914 \mathrm{~g}$ a.e./ha when applied to 4-leaf maize but only 64, 140, and $344 \mathrm{~g}$ a.e./ha when applied to 8-leaf maize, respectively. The predicted dose of MCPA amine that caused 5, 10, and $20 \%$ reduction in shoot dry weight of maize was 488,844 , and $1971 \mathrm{~g}$ a.e./ha when applied to 4-leaf maize and only 14,136, and $616 \mathrm{~g}$ a.e./ha when applied to 8-leaf maize, respectively. The predicted dose of MCPA amine that caused 5, 10, and 20\% yield reduction was 2557, 4247, and $>5040 \mathrm{~g}$ a.e./ha when applied to 4-leaf maize and 184, 441 , and $1245 \mathrm{~g}$ a.e./ha when applied to 8-leaf maize, respectively. Based on these results, glyphosate plus MCPA amine applied at the manufacturer's recommended dose of $630 \mathrm{~g}$ a.e./ha applied to 4-leaf maize has potential to cause injury but the injury is transient with no significant reduction in yield. However, when glyphosate plus MCPA amine is applied to 8-leaf maize it has the potential to cause significant injury and yield loss in maize.
\end{abstract}

\section{Introduction}

Canada produces nearly 11,000,000 metric tonnes of maize annually making it the 11th largest maize producer in the world [1]. Maize (Zea mays L.) is the third most valuable crop produced in Canada [1]. Greater than 95\% of maize produced in Canada is grown in Eastern Canada, with Ontario producing $62 \%$ of the national production $[1,2]$. Effective weed management is critical for maize producers to be competitive in the global market. Growers need weed management options that provide grass and broadleaved weed control with a wide margin of crop safety thereby resulting in minimal yield loss due to weed interference and higher net returns for producers.

In Ontario, most weed management studies in maize have focused on common weeds such as common lambsquarters (Chenopodium album L.), common ragweed (Ambrosia artemisiifolia L.), redroot pigweed (Amaranthus retroflexus L.), velvetleaf (Abutilon theophrasti Medicus), and foxtails
(Setaria spp.). In contrast, very little research has been conducted on weeds that affect only small percentage of the maize hectarage such as field horsetail (Equisetum arvense L.). Field horsetail is a competitive weed that has adapted to current agronomic practices and has moved into fertile grain fields [3]. It is increasing in prevalence in areas where growers rely on glyphosate for weed management since glyphosate is not very effective for the control of field horsetail. Field horsetail normally grows to a height of 30 to $40 \mathrm{~cm}$ and can be very competitive in crops as its rhizomes can form a thick mat underground during the summer growing season [4]. Significant yield losses have been reported in maize with heavy field horsetail stands that can reach densities of 400 shoots $\mathrm{m}^{-1}$ [3].

Currently registered postemergence (POST) herbicides in field maize in Ontario including nicosulfuron/rimsulfuron, flumetsulam, and nicosulfuron/rimsulfuron + flumetsulam do not provide adequate control of field horsetail in maize [5]. 
However, studies have shown that MCPA amine (dimethylamine salt of 2-methyl-4-chlorophenoxyacetic acid) applied alone or in tank mix with nicosulfuron/rimsulfuron or flumetsulam applied after emergence has potential to control field horsetail [4-8].

MCPA amine is a phenoxy herbicide that in addition to field horsetail controls many broadleaved weeds including pigweed spp., Polygonum spp., Ambrosia spp., Capsella bursapastoris (shepherd's purse), Taraxacum officinale (dandelion), Delphinium bicolor (buttercup), and Galeopsis tetrahit (hempnettle) $[9,10]$. MCPA amine is a growth regulating herbicide that affects respiration, translocation, and cell division which results in chlorosis of the growing points, growth inhibition, wilting, necrosis, and eventual death of susceptible plants within 3-5 weeks $[10,11]$.

MCPA amine is a desirable compliment to the current weed management programs in glyphosate-resistant maize. It provides an alternative mode of action thereby reducing the selection intensity for glyphosate-resistant weeds and can effectively control troublesome weeds such as field horsetail in maize. MCPA amine is currently registered in Ontario at 380-630 ga.e./ha applied to maize up to $15 \mathrm{~cm}$ in height. MCPA amine is more injurious to maize than either 2,4$\mathrm{D}$ or dicamba and therefore farmers are reluctant to use it. Earlier studies have shown as much as 5\% injury in maize with MCPA amine applied after emergence at $630 \mathrm{~g}$ a.e./ha [5]. However, MCPA is the best herbicide available in Ontario for the control of field horsetail in maize. There is little information on the sensitivity of glyphosate-resistant maize to glyphosate plus MCPA amine applied after emergence at various doses and application timings under Ontario environmental conditions. Determining the appropriate MCPA amine dose and application timing will help maize growers avoid crop injury and associated yield loss and provide an additional option for control of troublesome, glyphosate tolerant weeds such as field horsetail.

The objective of this research was to evaluate tolerance of field maize to tank mixes of glyphosate (900 g a.e./ha) plus MCPA amine applied after emergence at 79, 158, 315, 630, 1260,2520 , or $5040 \mathrm{~g}$ a.e./ha at either the 4 - or 8-leaf stage of maize.

\section{Materials and Methods}

A total of seven field trials were conducted at various locations in Ontario, Canada, during 2011-2013. There were 3 experiments at Ridgetown, ON, Canada, in 2011 and 2012 and one experiment at Harrow, ON, Canada, in 2013. Seedbed preparation at all sites consisted of autumn moldboard plowing followed by two passes with a field cultivator with rolling basket harrows in the spring.

Field trials were established as a randomized complete block design with four replications. Treatments included glyphosate 900 ga.e./ha (weed-free control) and glyphosate at 900 ga.e./ha plus MCPA amine at 79, 158, 315, 630, 1260, 2520 , or $5040 \mathrm{~g}$ a.e./ha. Plots consisted of four rows of maize that were spaced $0.75 \mathrm{~m}$ apart and were $8.0 \mathrm{~m}$ long. Maize was planted at the population of approximately 80,000 seeds $\mathrm{ha}^{-1}$ in May of each year. Herbicide treatments were applied with a $\mathrm{CO}_{2}$-pressurized backpack sprayer equipped with Hypro ULD120-02 nozzle tips (Hypro, New Brighton, MN) calibrated to deliver $200 \mathrm{~L} \mathrm{ha}^{-1}$ of water at $200 \mathrm{kPa}$. Herbicide applications were made with a $1.5 \mathrm{~m}$ boom with four nozzles spaced $50 \mathrm{~cm}$ apart. Herbicide treatments were applied at 4leaf or 8-leaf maize (each timing to a separate set of plots). All plots including the nontreated control were kept weed-free by hand weeding as required.

Maize injury was visually estimated on a scale of 0 (no injury) to $100 \%$ (complete plant death) at $1,2,4$, and 8 weeks after the corresponding treatment application (WAT). Maize shoot dry weight was determined 4 WAT by cutting 10 plants per plot at the soil surface, drying at $60^{\circ} \mathrm{C}$ to constant moisture. At 8 WAT, maize height was measured for 10 plants per plot and brace root malformation was rated on a scale of 0 (no malformation) to 10 (severe malformation). Percent lodging (goose-necked or falling stalks) was rated prior to harvest, approximately 16 WAT. The maize crop was harvested with a small plot combine, weight and seed moisture content were recorded, and yields were adjusted to $15.5 \%$ seed moisture content.

Data were analyzed using nonlinear regression (PROC NLIN) in SAS 9.2 [12]. Maize dry weight, height, and yield were converted to a percent of the glyphosate-only check prior to analysis.

All parameters were regressed against MCPA amine dose, designated as RATE in the equations. The equation used for percent crop injury, brace root injury, and lodging (rectangular hyperbola based on Cousen's yield loss model) was

$$
Y=\frac{(i * \mathrm{RATE})}{(1+(i * \mathrm{RATE} / a))}
$$

where $a$ is the upper asymptote and $i$ is the initial slope. For percent shoot dry weight, a descending rectangular hyperbola based on Cousen's model was used:

$$
Y=d\left(1-\frac{(b * \mathrm{RATE})}{100(1+b * \mathrm{RATE} / c)}\right),
$$

where $b$ is the initial slope, $c$ is the lower asymptote, and $d$ is the $Y$-intercept. The equation for percent maize height and yield was an inverse exponential:

$$
Y=f+g *(\exp [-h * \mathrm{RATE}]),
$$

where $f$ is the lower asymptote, $g$ is the magnitude of the response, and $h$ is the slope of the response.

\section{Results and Discussions}

Regression equations were used to calculate predicted MCPA rates (g a.e./ha) that would result in a 5,10 , or $20 \%$ crop/brace root injury or lodging or a 5,10 , or $20 \%$ reduction in percent crop dry weight, height, or yield, relative to the glyphosateonly check. If any MCPA rate was predicted to be higher than 5040 ga.e./ha, it was simply expressed as “ $>5040$ ” since it would be improper to extrapolate outside the range of rates evaluated in these experiments. 
TABLE 1: Parameter estimates and predicted MCPA rates from regression models of visible percent field maize injury 1, 2, 4, and 8 WAT, brace root injury 8 WAT, and percent lodging prior to harvest ${ }^{\mathrm{a}}$.

\begin{tabular}{|c|c|c|c|c|c|c|}
\hline \multirow{3}{*}{ Crop injury } & \multirow{3}{*}{ Application timing } & \multicolumn{2}{|c|}{ Parameter estimates $^{\mathrm{b}}( \pm \mathrm{SE})$} & \multicolumn{3}{|c|}{ Predicted MCPA rate ${ }^{c}$} \\
\hline & & $a$ & $i$ & $R_{5}$ & $R_{10}$ & $R_{20}$ \\
\hline & & $\%$ & & & g a.e./ha & \\
\hline \multirow{2}{*}{1 WAT } & 4-leaf corn & $45(6)$ & $0.015(0.002)$ & 380 & 867 & 2415 \\
\hline & 8-leaf corn & $90(5)$ & $0.052(0.005)$ & 101 & 215 & 492 \\
\hline \multirow{2}{*}{2 WAT } & 4-leaf corn & $56(9)$ & $0.016(0.002)$ & 339 & 751 & 1914 \\
\hline & 8-leaf corn & $78(4)$ & $0.056(0.005)$ & 95 & 204 & 479 \\
\hline \multirow{2}{*}{4 WAT } & 4-leaf corn & $63(22)$ & $0.009(0.002)$ & 630 & 1380 & 3403 \\
\hline & 8-leaf corn & $65(4)$ & $0.081(0.012)$ & 67 & 146 & 357 \\
\hline \multirow{2}{*}{8 WAT } & 4-leaf corn & $21(6)$ & $0.008(0.003)$ & 820 & 2414 & $>5040$ \\
\hline & 8-leaf corn & $63(5)$ & $0.085(0.014)$ & 64 & 140 & 344 \\
\hline \multirow{2}{*}{ Brace root } & 4-leaf corn & $3(1)$ & $0.002(0.001)$ & 267 & 671 & 2740 \\
\hline & 8-leaf corn & $9(0)$ & $0.068(0.009)$ & 8 & 17 & 38 \\
\hline \multirow{2}{*}{ Lodging } & 4-leaf corn & $0(0)$ & $0(0)$ & - & - & - \\
\hline & 8-leaf corn & $37(7)$ & $0.034(0.013)$ & 168 & 400 & 1283 \\
\hline
\end{tabular}

${ }^{\mathrm{a}}$ WAT, weeks after treatment.

${ }^{\mathrm{b}}$ Regression parameters ((1), rectangular hyperbola): $a$, upper asymptote; $i$, initial slope.

${ }^{\mathrm{c}} R_{5}, R_{10}$, and $R_{20}$ are the MCPA rates predicted to result in 5,10 , or $20 \%$ crop injury.

3.1. Crop/Brace Root Injury or Lodging. For all injury ratings MCPA amine caused more injury when applied to 8-leaf maize compared to when it was applied to 4-leaf maize. At 1 WAT, the predicted dose of MCPA amine that caused 5, 10 , and $20 \%$ injury was 380,867 , and $2415 \mathrm{~g}$ a.e./ha when applied to 4 -leaf maize but only 101, 215, and $492 \mathrm{~g}$ a.e./ha when applied to 8-leaf maize, respectively (Table 1), indicating that MCPA amine is far more injurious to maize when the application timing is delayed. At 2 WAT, the predicted dose of MCPA amine that caused 5, 10, and 20\% injury was 339,751 , and 1914 g a.e./ha when applied to 4 -leaf maize but only 95,204 , and $479 \mathrm{~g}$ a.e./ha when applied to 8 leaf maize, respectively.

Generally beyond 2 WAT, MCPA amine applied at $630 \mathrm{~g}$ a.e./ha or lower doses to 4 -leaf maize caused no visible injury in maize. At $4 \mathrm{WAT}$, the predicted dose of MCPA amine that caused 5,10 , and $20 \%$ injury was 630,1380 , and $3403 \mathrm{~g}$ a.e./ha when applied to 4-leaf maize and 67, 146, and $357 \mathrm{~g}$ a.e./ha when applied to 8-leaf maize, respectively (Table 1). At 8 WAT, the predicted dose of MCPA amine that caused 5, 10, and 20\% injury was 820,2414 , and $>5040$ g a.e./ha when applied to 4 -leaf maize and 64,140 , and $344 \mathrm{~g}$ a.e./ha when applied to 8-leaf maize, respectively.

The predicted dose of MCPA amine that caused 5, 10, and $20 \%$ brace root malformation was 267,671 , and $2740 \mathrm{~g}$ a.e./ha when applied to 4 -leaf maize and only 8,17 , and $38 \mathrm{~g}$ a.e./ha when applied to 8-leaf maize, respectively (Table 1). There was no lodging injury when MCPA amine was applied at doses evaluated to 4-leaf maize but the predicted dose of MCPA amine that caused 5,10 , and $20 \%$ lodging injury was 168,400 , and $1283 \mathrm{~g}$ a.e./ha when applied to 8 leaf maize, respectively (Table 1).

In other studies, Buhler in 1991 [13] found no visible injury or reduction in plant stand in maize with other grass herbicides such as metolachlor and atrazine. However, other studies have shown as much as $28 \%$ injury in maize with herbicides such as alachlor and metolachlor depending on environmental conditions [14-17]. Other herbicides such as rimsulfuron, nicosulfuron, nicosulfuron plus rimsulfuron, and primisulfuron have been shown to cause no injury in maize [18]. However, Swanton et al. [19] found as much as $19 \%$ injury in maize with sulfonylurea herbicides such as nicosulfuron and rimsulfuron.

3.2. Shoot Dry Weight and Height. The predicted dose of MCPA amine that caused 5, 10, and 20\% reduction in shoot dry weight of maize compared to the control was 488,844 , and $1971 \mathrm{~g}$ a.e./ha when applied to 4-leaf maize and 14, 136, and $616 \mathrm{~g}$ a.e./ha when applied to 8-leaf maize, respectively (Table 2). MCPA amine reduced shoot dry weight much more when applied to 8-leaf maize compared to when it was applied to 4-leaf maize (Table 2).

There was no effect on plant height when MCPA amine was applied to 4-leaf maize but the predicted dose of MCPA amine that reduced height by $5 \%$ was only $396 \mathrm{~g}$ a.e./ha when applied to 8-leaf maize (Table 2). In other studies Buhler [13] found no reduction in maize height with other herbicides such as metolachlor when applied with atrazine. However, Swanton et al. [19] found significant height reduction with sulfonylurea herbicides such as nicosulfuron and rimsulfuron in maize.

3.3. Yield. Maize was more tolerant to MCPA amine when applied at the 4-leaf stage than the 8-leaf stage. The predicted dose of MCPA amine that caused 5, 10, and 20\% yield reduction compared to the control was 2557, 4247, and $>5040 \mathrm{~g}$ a.e./ha when applied to 4-leaf maize and only 184 , 
TABLE 2: Parameter estimates and predicted MCPA rates from regression models of percent maize dry weight (4 WAT), height (8 WAT), and yield $^{\mathrm{a}}$.

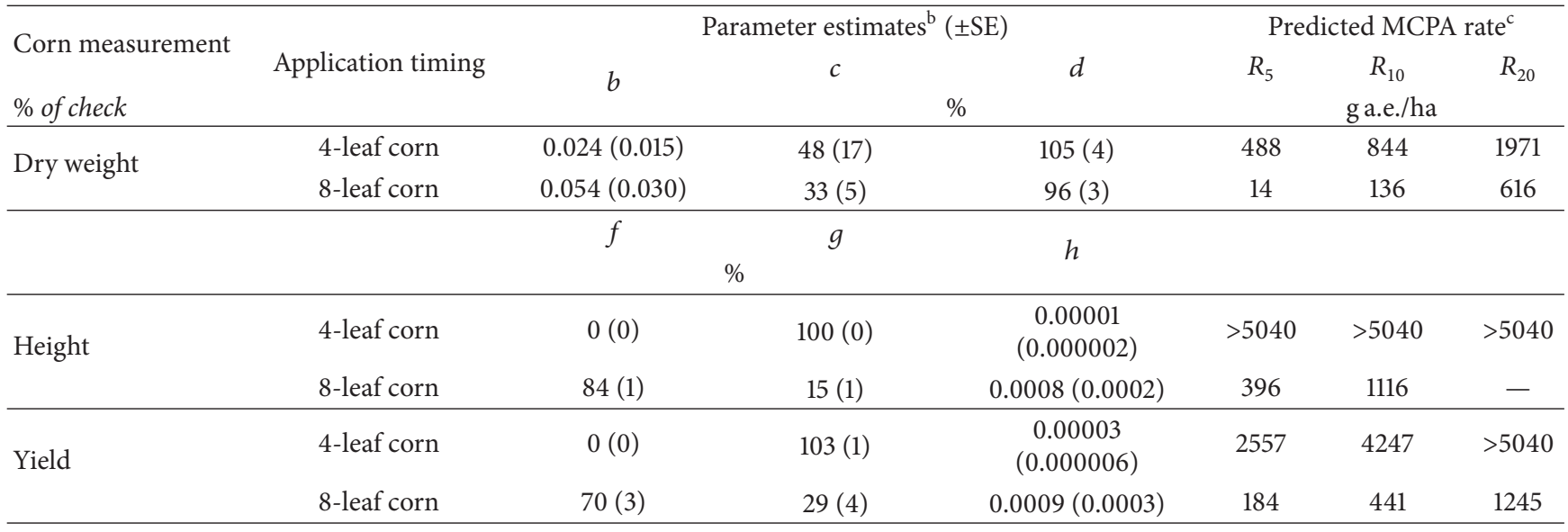

${ }^{\mathrm{a}}$ WAT, weeks after treatment.

${ }^{\mathrm{b}}$ Regression parameters ((2), descending rectangular hyperbola): $b$, initial slope; $c$, lower asymptote; $d, Y$-intercept.

((3), inverse exponential): $f$, lower asymptote; $g$, magnitude of response; $h$, slope of response.

${ }^{\mathrm{c}} R_{5}, R_{10}$, and $R_{20}$ are the MCPA rates predicted to result in a 5, 10, or $20 \%$ reduction in percent corn dry weight, height, and yield.

441, and $1245 \mathrm{~g}$ a.e./ha when applied to 8-leaf maize, respectively (Table 2).

In other studies, Buhler [13] found significant yield reduction with herbicides such as metolachlor with atrazine in maize. Other herbicides such as nicosulfuron plus rimsulfuron have been shown to cause as much $16 \%$ yield reduction in maize [19].

\section{Conclusions}

Based on these results, glyphosate plus MCPA amine applied at the manufacturer's recommended dose of $630 \mathrm{~g}$ a.e./ha to 4-leaf maize has the potential to cause injury in maize but the injury is transient with no significant effect on maize yield. In contrast, glyphosate plus MCPA amine applied at the manufacturer's recommended dose of $630 \mathrm{~g}$ a.e./ha to 8-leaf maize has the potential to cause significant injury resulting in substantial yield losses at harvest time. Glyphosate plus MCPA amine applied early after emergence is a desirable compliment to the current weed management programs in maize, especially for weeds that are naturally tolerant to glyphosate such as field horsetail. In addition, this tank mix will increase the spectrum of annual, biennial, and perennial broadleaf weeds control and will reduce the selection intensity for glyphosate-resistant biotypes.

\section{Conflict of Interests}

The authors have no conflict of interests to report.

\section{Acknowledgments}

Funding for this project was provided by the Grain Farmers of Ontario and the GF2 Program of Agricultural Adaptation Council.

\section{References}

[1] Statistics Canada, Corn: Canada's Third Most Valuable Crop, 2015, http://www.statcan.gc.ca/pub/96-325-x/2014001/article/ 11913-eng.htm.

[2] K. Kulasekera, Grain Corn: Area and Production, by County, Ministry of Agriculture, Food and Rural Affairs, Ontario, Canada, 2014, http://www.omafra.gov.on.ca/english/stats/crops/ estimate_new.htm\#metric.

[3] W. J. Cody and V. Wagner, "The biology of Canadian weeds. 49. Equisetum arvense L.," Canadian Journal of Plant Science, vol. 61, pp. 123-133, 1980.

[4] T. K. James and A. Rahman, "Chemical control of field horsetail (Equisetum arvense)," New Zealand Plant Protection, vol. 63, pp. 102-107, 2010.

[5] P. H. Sikkema, Weed Control Trials Research Report, University of Guelph Ridgetown Campus, Ridgetown, Canada, 2013.

[6] C. C. Bell and A. I. Popay, "Chemical control of field horsetail," in Proceedings of the 41st New Zealand Weed and Pest Control Conference, vol. 41, pp. 66-69, 1988.

[7] J. Doll, "Biology and control of field horsetail (Equisetum arvensis L., Horsetail Family)," 2001, http://fyi.uwex.edu/ weedsci/2001/05/02/biology-and-control-of-field-horsetail/.

[8] P. B. Hoyt and A. C. Carder, "Chemical control of field horsetail," Weeds, vol. 10, no. 2, pp. 111-115, 1962.

[9] Ontario Ministry of Agriculture; Food and Rural Affairs (OMAFRA), "Guide to weed control," Publication 75, Ontario Ministry of Agriculture, Food and Rural Affairs (OMAFRA), Toronto, Canada, 2014.

[10] D. L. Shaner, Herbicide Handbook, Weed Science Society of America, Champaign, Ill, USA, 10th edition, 2014.

[11] D. Lemerle, R. B. Hinkley, C. R. Kidd, and A. R. Leys, "Symptoms of injury caused by herbicides in wheat and barley," Advisory Bulletin, Department of Agriculture, New South Wales, vol. 4, pp. 1-14, 1986.

[12] Statistical Analysis Systems (SAS), The SAS System for Windows, Release 9.2., Statistical Analysis Systems Institute, Cary, NC, USA, 2008. 
[13] D. D. Buhler, "Early preplant atrazine and metolachlor in conservation tillage corn (Zea mays)," Weed Technology, vol. 5, no. 1, pp. 66-71, 1991.

[14] G. A. Dixon, E. W. Stoller, and M. D. McGlamery, "Acetanilide herbicides for yellow nutsedge (Cyperus esculentus) control in corn (Zea mays)," Weed Science, vol. 28, no. 5, pp. 593-598, 1980.

[15] G. A. Dixon and E. W. Stoller, "Differential toxicity, absorption, translocation, and metabolism of metolachlor in corn (Zea mays) and yellow nutsedge (Cyperus esculentus)," Weed Science, vol. 30, pp. 225-230, 1982.

[16] J. R. Leavitt and D. Penner, "Protection of corn (Zea mays) from acetanilide herbicidal injury with the antidote R-25788," Weed Science, vol. 26, no. 6, pp. 653-659, 1978.

[17] C. J. Peter and B. Weber, "Adsorption, mobility, and efficacy of alachlor and metolachlor as influenced by soil properties," Weed Science, vol. 33, pp. 874-881, 1985.

[18] P. H. Sikkema, C. Kramer, J. D. Vyn, J. J. Kells, D. E. Hillger, and N. Soltani, "Control of Muhlenbergia frondosa (wirestem muhly) with post-emergence sulfonylurea herbicides in maize (Zea mays)," Crop Protection, vol. 26, no. 10, pp. 1585-1588, 2007.

[19] C. J. Swanton, K. Chandler, M. J. Elmes, S. D. Murphy, and G. W. Anderson, "Postemergence control of annual grasses and corn (Zea mays) tolerance using DPX-79406," Weed Technology, vol. 10, no. 2, pp. 288-294, 1996. 


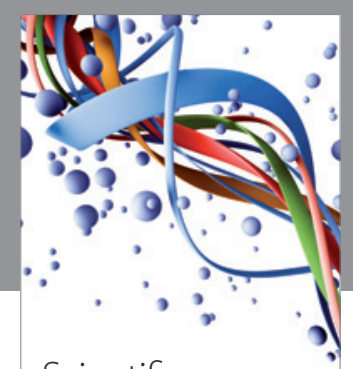

Scientifica
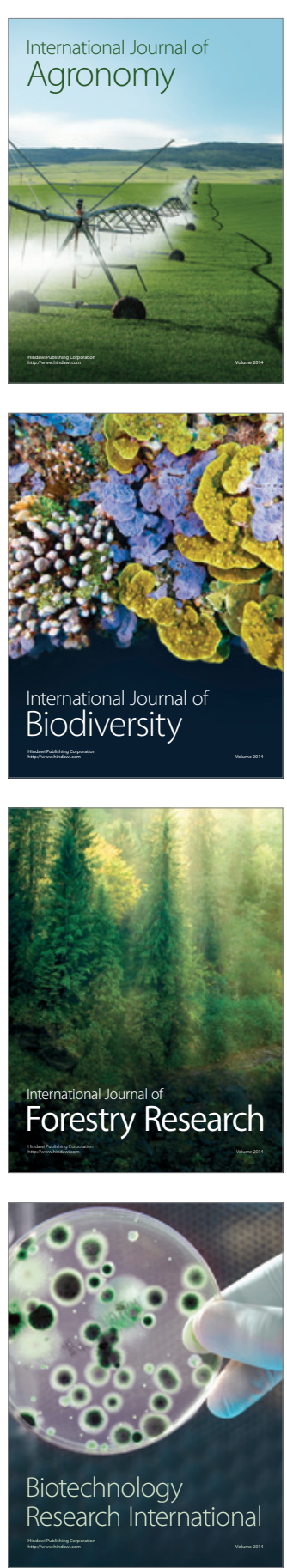
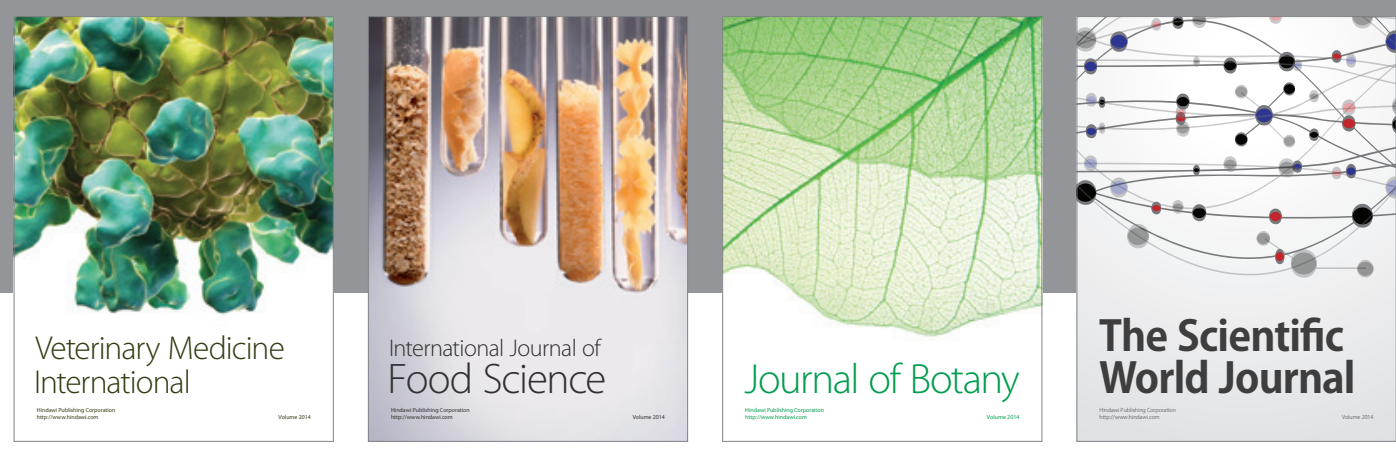

The Scientific World Journal
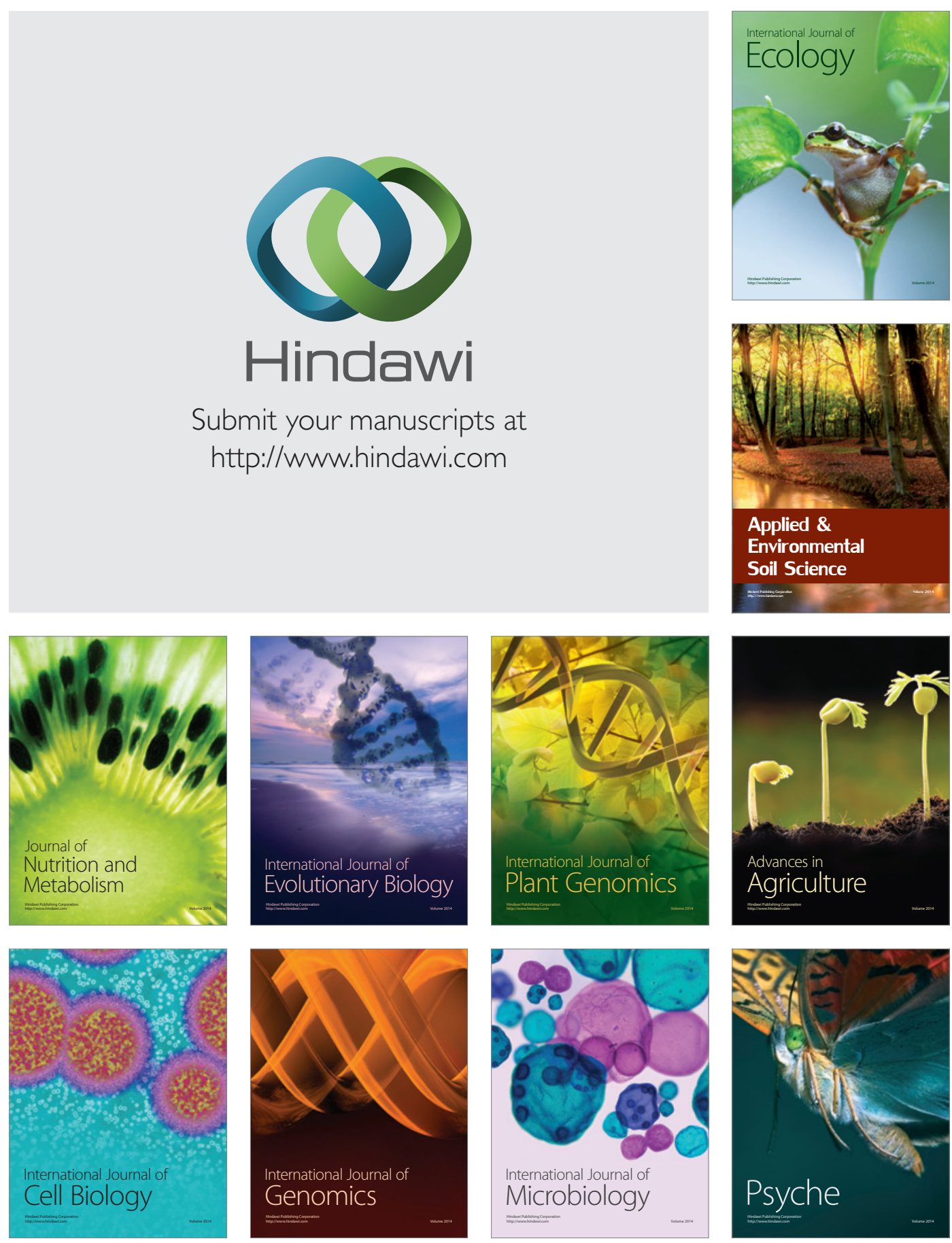